\title{
6
}

\section{At the nexus of state and society: Continuities and discontinuities between the legal system and popular justice}

Nonstate punishment of, or vigilante action against, those accused of blasphemy is usually seen in stark opposition to the state legal system. However, there are many people who do not see state and nonstate punishments as expressions of two distinct systems of justice. Instead, they have a coherent worldview in which both state and nonstate punishments are simultaneously justified. There are also those who distinguish between the law and vigilante action, but even in so doing, they coopt the popular narratives that glorify acts of nonstate violence against those accused of blasphemy. In this chapter, I will demonstrate the continuities and discontinuities between the legal system and popular justice from the points of view of two groups of people who I believe are located at the nexus of the state and civil society. The first group is an organisation of lawyers who voluntarily represent the accusers in court to ensure that the state punishes the accused for their alleged offence of blasphemy. These lawyers also represent nonstate punishers in the courts, advocating that they should not be held culpable by the state. Therefore, this group of lawyers supports both state and nonstate punishment of alleged blasphemers. The second group are the state judges deciding on the cases of blasphemy. While the lawyers stand truly at the nexus of state and society as they mediate between the two, the judges officially 
represent the state but are also a part of the society. My discussion of the lawyers is based on my ethnographic fieldwork with them over several months, and the discussion of the judges' discourse is based on publicly available court judgements.

In the first section of this chapter, I will discuss the discourse of a specific group of lawyers. These lawyers engage with multiple arguments and narratives to construct a coherent worldview in which they simultaneously support state and nonstate punishment of alleged blasphemers. I will discuss the major narratives with which they engage, such as reason-based justifications, Sufi ideals of devotion and passionate love in which they actively defy reason and textual interpretations of religious sources. This section will demonstrate how they believe in multiple sources of legitimacy and strategically construct their arguments in various circumstances. I argue that the multiple and apparently dissonant narratives provide the lawyers with meaning as well as resources for strategic argumentation. I contend that the lawyers' discourse demonstrates a continuity rather than a dissonance between reason and passion as they construct a coherent worldview in which both state and nonstate punishments are justified.

In the second section of this chapter, I will discuss the discourse of judges. Judges also draw on multiple sources of legitimacy — state law and Western legal concepts, textual sources of Islamic law and popular narratives such as that about the heroic figure of Ghazi Ilmuddin-in constructing their arguments. An analysis of court judgements will show that these sources can be used in different ways. For example, religious sources are referred to in judgements both in favour of and against the accused. The lower courts, sessions courts, usually refer to religious sources (Quran and hadith) and popular narratives when making decisions against the accused. Higher court judges may employ the same sources to reach the opposite decision, in favour of the accused. Hence, judges exercise discursive reasoning to reach various decisions while drawing on the same set of sources. Nevertheless, even in the boldest of the judgements in favour of the accused, judges have to appeal not only to the textual interpretations of religious sources, but also to popular narratives concerning nonstate punishment. Hence, I suggest the legal system and popular justice should be seen as extensions of each other rather than two distinct and competing domains. Through an analysis of the discourse of lawyers and judges, I argue against the dichotomies of reason/passion and state/nonstate in understanding the legitimate punishment of blasphemy in Pakistan. 


\section{The discourse of lawyers: Reason, passion and strategic argumentation}

Mustafa Chaudhry, a soft-spoken middle-aged man with a short greying beard, wearing a black suit that is the uniform for lawyers, enters the Lahore Sessions Court every morning. Most days he is accompanied by three or four male lawyers, all in their black suits, and a female lawyer wearing a hijab over a black coat and a traditional white dress. This is his core team but on occasions there may be many more lawyers accompanying him. Sitting on benches in tin sheds in the concrete yards of the Sessions Court, their day starts with cups of tea. The 'tea boys' highly regard Chaudhry and his team, as do other lawyers passing by, who stop to pay their respects. As they sip tea, they also organise the files for the cases they are to attend that day. Every day, they appear in several cases of blasphemy as volunteer private prosecution lawyers for the complainants. Sometimes, their daily agenda also includes attending hearings as volunteer defence lawyers for those who have carried out violent punishment of alleged blasphemers outside the legal system. They believe they are doing so for love of the Prophet Muhammad, as is their religious duty. According to them, each and every blasphemer from around the country must be punished harshly, and those who punish the accused outside the law are the epitome of the passionate love and devotion that a Muslim should have for the Prophet Muhammad.

Chaudhry heads Khatm-e-Nabuwwat Lawyers' Forum (KNLF), an 800-member organisation of lawyers on a dual mission to prosecute all cases of blasphemy across Pakistan and defend those who punish the alleged blasphemers outside the law. The founding members of the KNLF, which is based in Lahore, claim they are all professional lawyers who offer their services voluntarily for the sake of namoos-e-risaalat ('honour of the Prophet') in the path of Allah. They have a women's wing as well that assists the forum especially with cases of blasphemy in which the accused are women (recall that the officially named accusers or complainants are rarely women). The KNLF lawyers claim that whenever there is an allegation of blasphemy, anywhere in Pakistan, they visit, meet the accusers and the accused and assist in the prosecution. They assert that they 'conduct proper research' as to whether or not the offence was actually committed before offering their legal assistance to the complainants. However, during my five months of regular interaction with them, I came across many instances in which they decided to support the accusers the 
moment they heard of the incident, before verifying the details of the case being reported. Nevertheless, they always maintained their claim that they work without bias or prejudice against the accused, and that they fight only for the love of Allah and his Prophet. For cases outside Lahore, they assist and support local lawyers from the relevant areas. Many of those local lawyers are members of the forum, too.

Besides the registered members, many other lawyers also join the KNLF when they appear before the courts for blasphemy-related trials. KNLF has a communications team that is responsible for circulating messages among the lawyers' community about the time, date and location of blasphemy-related trials. When I asked Chaudhry about the purpose of non-member lawyers attending the trials, he said: 'Every Muslim lawyer wants to register his presence in the court of Allah'. It is worth noting that these lawyers refer to the courts of law as the 'court of Allah', but they are not accepted as the only courts of Allah. In the previous chapter, I mentioned that religious leader Khadim Hussain Rizvi did not accept the 'courts' of the modern state of Pakistan as the places where Islamic justice is delivered. For the KNLF lawyers, however, the state courts represent courts of Islamic justice in most cases.

KNLF members have appeared in hundreds of cases of blasphemy since the 1990s. During the period of my research with them, they appeared in multiple trials for blasphemy (sometimes as many as half a dozen) every day. I accompanied them to many of these trials and spent the remainder of my time with them either at their bench in the Lahore Sessions Court or at the personal office of the KNLF president, Mustafa Chaudhry. The two most iconic cases they have represented in the Supreme Court of Pakistan are Asia Bibi vs The State and Mumtaz Qadri vs The State. In the former, they supported punishment according to state law for a woman accused of insulting the Prophet Muhammad. In the latter, they supported the perpetrator of the nonstate killing of Salman Taseer, who was accused of blasphemy for his criticism of Pakistan's blasphemy laws. Thus, they support state and nonstate punishment of alleged blasphemers at the same time.

My first meeting with the KNLF's founding members was an uneasy one, with suspicion and mistrust on both sides. I was afraid they would disapprove of me and my personal ideas (if they found out what they were) as not conforming with their religious understanding. I was uncertain of the consequences of such an evaluation from their side. They, on the other hand, were suspicious of my motives. I had Chaudhry's phone 
number and called him to ask for an interview. I told him I was a $\mathrm{PhD}$ student researching the blasphemy laws in Pakistan. When I arrived at his small third-floor office in an old, tattered building on a very busy street just behind the Lahore High Court, he and a few other members of his team, including the head of the women's wing, were present. It was a hot September afternoon and they cheerfully offered me tea and soft drink. However, before I could start talking to them, they asked me several questions. They asked me about my religion and sect, my 'school of thought', the reason I was interested in the blasphemy laws, why I chose it as my research topic and my take on the issue of blasphemy. I hesitantly answered their questions about my religious and sectarian background. They were somewhat relieved to hear that I was from a Shia family as Shias are considered much closer to the Sunni Barelwis when it comes to reverence of holy personalities and objects-compared with Sunni Deobandis, who criticise both the Sunni Barelwis and Shias for veneration of persons and objects. Nevertheless, I told them that, as a researcher, I was interested in understanding the viewpoints of different parties on the issue of blasphemy and that I had formed no opinions on the matter. Naturally, they were suspicious of me and thus gave very calculated responses to my questions in that first meeting.

It is important to see how the lawyers' answers in the first meeting differed from the opinions they shared in my later meetings with them, when they had become more comfortable with my presence. During my interactions with them, they went from defending the state law to arguing that there may be exceptional circumstances in which punishment can be delivered outside the legal system, to presenting nonstate punishers as the epitome of devotional and passionate love even in the absence of 'exceptional circumstances'. I will begin by discussing their initial responses in which they defended the law concerning the punishment of blasphemy. These responses shed light on how the KNLF members engage in a dialogue with a legal framework that claims to embody Islamic law but is also embedded in Western legal concepts and structures. Such an engagement is a persistent concern for them and shapes their ideas and responses. In my first meeting with them, when I asked them about the appropriate punishment for a blasphemer, Chaudhry replied:

When the law is present, we should refer the cases [of insult to Islam and the Prophet Muhammad] to the law. The purpose of law in any society is to maintain order. If people get up and start punishing other people on their own, there will be no peace left in the society. Rule of law must always prevail. 
He further asserted:

If we did not have the blasphemy laws in place, can you imagine what would have been the fate of all the accused in these cases? The justice would have been served in the streets and neighbourhoods. So, the blasphemy law is indeed a great blessing for the blasphemers. It gives them a chance to clarify themselves in case there has been a misunderstanding or false allegation. In the absence of this law, Ghazi Ilmuddin's law would be implemented. There are so many cases currently being heard in the courts. The trials are going on. These are our courts; we must support them. People should be made aware of the existence of the blasphemy laws and their right usage. The appropriate way is to bring any incident to the court's notice and support it with evidence.

Not only did he justify the need for the blasphemy laws, but also he praised the procedures required for registering a case, the trial methods and even the court judgements. After describing the whole procedure from the instant an accusation is levelled to court judgements, he said:

You see, this is a foolproof method already in place to prevent the misuse of blasphemy laws. With all the safeguards against false reporting, there is no space left for the misuse of blasphemy laws in the legal procedures.

He emphasised several times that there was no misuse of the blasphemy laws and any such claims were mere propaganda from those who wanted to undermine the laws protecting Islam. He was referring here to the state law and Western legal principles in which he and his fellow lawyers had been trained. Nevertheless, this sense of legality (which remained present in their discussions throughout the course of my study) was not the only frame of moral reference on which they drew. They qualified their understanding of the law and legality with alternative ideas of legality derived from their religious and personal beliefs. One of the narratives they employed to qualify their understanding of the 'rule of law' and the legality of state law was based on the idea of 'exceptional circumstances'.

\section{Exceptional circumstances, ineffective state laws and helpless victims}

Having praised Pakistan's existing blasphemy laws, and after emphasising the importance of the 'rule of law', Chaudhry qualified his opinion: 
There may be exceptional circumstances when somebody is helpless. For example, let us look at the case of Salman Taseer ... There were many applications to register a case against him. Petitions were made, but the court ruled that, as a governor, he was afforded protection by the Constitution. So, a case could not be registered against him. Both Lahore and Islamabad high courts dismissed petitions against him. There were protests from religious organisations all across the country. Mumtaz Qadri himself took an application to a police station to register the case. The police reproached him, calling him a moulvi [in this instance, a derogatory term for a person with a beard] and asked him to leave. ${ }^{1}$ Despite all these protests and petitions against him, no apology or statement was issued by the governor or his spokesperson. He not only stood by his [blasphemous] words and [transgressive] actions, he further said on TV that he keeps the moulvis at the tip of his shoe. In such circumstances, there had to be an ultimate reaction. If the government had upheld the law created by the state, there would not have been the need for any Qadri to be born. So, in such a situation, exceptional circumstances have to be taken into account.

The 'exceptional circumstances' to which Chaudhry refers are imagined in relation to the state's inability to and ineffectiveness in carrying out desired punishments. Chaudhry explained:

The nonstate punishment takes place when people feel that justice will not be served, and the blasphemer will be able to get away with it, as happened in the case of Salman Taseer. If the government had asked Taseer to resign and made him face the charges in the court, this would not have happened. Whenever there is mistrust between a person and the government, such incidents [of nonstate punishment] will take place.

Therefore, we see that an emphasis on the authenticity of legal claims (according to state law) and the ineffectiveness of the existing law, inducing a sense of helplessness, go hand in hand. This tension between the legality of state law and an extended legality of nonstate violence due to the ineffectiveness of state law remained a pertinent theme of my discussions with the members of KNLF. The sense of helplessness in Chaudhry's account rests on the image of lovers of the Prophet-

1 This story does not exist on the official legal record. Despite being Qadri's defence lawyer, Chaudhry did not bring it up in his legal arguments in the court. 
true Muslims-as victims due to the ineffectiveness of the law and the government in delivering justice by punishing alleged blasphemers. It is derived from a feeling of being attacked, since they perceive themselves as peaceful Muslims who are attacked (by a blasphemer) and forced to act in a certain way. One day, while at Chaudhry's office, I met one of his clients, a Sunni Barelwi man. He wanted to register a complaint about disrespect of the 'holy personages' against an Ahmadi publisher who had published allegedly disrespectful material against prophets (Muhammad and Jesus) and Imam Hussain (the grandson of Prophet Muhammad). In explaining this particular case to me, the KNLF lawyers said:

These people [the Ahmadis] are very powerful. Due to their influence and contacts, it is very difficult to get a complaint registered against them. Many people have tried to register a FIR [first information report] against them but the police refuse. We have fatwas from religious organisations and orders from some government authorities as well. We even had an order issued from the Lahore High Court that a police case should be registered, despite which no action has been taken by the police so far.

After showing me several documents with orders and fatwas from religious scholars and organisations against the accused publisher, they continued:

These people publish such derogatory material that any Muslim who reads it will be severely hurt. There is no way to rectify the hurt. It is as if someone cuts the main artery of an animal and leaves it to bleed, to die a slow and painful death, and does not even offer water. Disrespect of the Prophet is like cutting our main artery ... They tie our hands and feet and leave us agonised. In such a situation, if some devout Muslim resorts to the desperate measure of killing a blasphemer, the whole world will reproach us for taking the law into our own hands and present us as violent people.

The perception is therefore that the first instance of attack or violence is perpetrated by the blasphemer; the reaction of killing the blasphemer is merely self-defence by the helpless victims of their attacks. These narratives of helplessness and injustice serve as an alternative point of reference for ideas of legality. They also induce sentiments of victimhood that fuel the passion for hero-worship - that is, the glorification of those who retaliate and are able to deliver punishment to the blasphemers. The more powerful the alleged blasphemer is perceived to be, the higher is the reverence accorded to her/his killer. Qadri is seen not only as the killer of 
an alleged blasphemer, but also as a symbol of resistance to power as it was the governor of Punjab he took down. He faced a much higher degree of helplessness with the highest of odds stacked against him. The number of people who came on to the streets at Qadri's funeral, the enormous amount of funds that were collected by the Qadri Foundation after his execution by the state, the construction of a shrine on his grave and the flocking of devotees to it (Pasha 2016) —all are signs of the reverence bestowed on the killer of a blasphemer, amplified in accordance with the narrative of helplessness and victimhood.

While the narrative of helplessness and injustice provides the lawyers with a compelling reason-based argument to justify their extended framework of moral legality, it is not the complete story. The explanation of nonstate violence as a consequence of 'exceptional circumstances' does not hold true if we look at my later interactions with the lawyers. The KNLF lawyers proudly supported those who punished blasphemers outside the law even when there were no exceptional circumstances and when the law was already in action. In such cases, they relied on ideas of devotion and passionate love-yet another narrative they used to construct their arguments. I will now discuss the narrative of devotion, passionate love and intuitive knowledge that drives the lawyers' judgements.

\section{Devotion, passionate love and intuitive knowledge of the heart}

One morning, after a hearing in the Lahore High Court that I attended with the KNLF team, Chaudhry suggested that we go to his office where a woman was waiting for him. She was the mother of a 23 -year-old, Ahmed, who was sentenced to death in 2012 and imprisoned for killing a man accused of burning the Quran. I accompanied Chaudhry to his office and met this woman and another of her sons, who was accompanying her. She was a thin elderly woman, in very simple clothes and a white chaadar (large piece of cloth covering the head and body); her son was also a very plain village man. As per their account, one winter night during Ramzan (the Islamic month of fasting) a man burnt a Quran in their village, near a local shrine. This man was aged in his thirties and was a person of 'bad reputation'. He was known to be a thief and used to tease women in the community. He was also a drug addict. There were no witnesses to the act, but people who lived nearby found a burnt copy of the Quran and accused him of having burnt it. Ahmed, who was 15 years old and 
a student in the ninth grade at the time, lived in the same neighbourhood. He was a passionate boy. On learning about the incident, he went to the man accused of burning the Quran and asked him why he had done so. The man said: 'Yes, I have burnt the Quran, what can you do now?' Ahmed stabbed him with a knife and killed him on the spot.

After Ahmed's mother told us the story, with tears in her eyes, Chaudhry asked her whether she believed her son had committed the right deed. She said she thought he did the right thing because the dead man was 'a nuisance to the community anyway'. Chaudhry again asked her, in an assertive tone, whether it was due to the deceased being a blasphemer by burning a Quran that she thought her son's action was right. She said, more thoughtfully this time: 'Of course, burning the Quran was the prime reason and the foremost concern for us is the gracious Prophet'. Chaudhry declared that only if she was happy with and proud of her son's act would he take up the case for no charge and fight for Ahmed's freedom. He told her and her other son that Ahmed was a ghazi ('a successful warrior') and she was lucky to have such a brave, naik aur kismet wala ('pious and chosen') son. He said only lucky and blessed people were given such opportunities for spiritual fulfilment. He reassured Ahmed's agonised mother not to worry and to be thankful for the path (of love) on which her son had set his foot.

Ahmed's family was poor and lived in a small village. His father had died about 15 years earlier. Ahmed's three brothers worked as manual labourers in building and construction. They did not own land but had their own house. Chaudhry had written a letter to ask Ahmed's mother and brother to come to visit him in Lahore to appeal Ahmed's death sentence. He paid for their travel to and from the city. He had also bought some women's and children's clothes (in various sizes) and gave them to Ahmed's mother. He asked me to open the bag and show the clothes to her and her son before giving them away. Chaudhry proudly told me after this episode that he was fighting for many other ghazis who had killed blasphemers. In Ahmed's case, there were no 'exceptional circumstances' that would have made punishing the accused blasphemer through the state legal system unachievable. Ahmed acted solely on a whim and did not try to access the law in this matter. Nevertheless, Chaudhry not only supported him wholeheartedly, but also proactively reached out to his family to provide them with free legal services to save Ahmed from his death 
sentence. He told me that it was through these 'selfless' deeds (of helping the ghazis of Allah and his Prophet) that he hoped to receive salvation and success in the afterlife.

There were many other cases in which the KNLF lawyers were advocating for ghazis who had committed acts of violence against alleged blasphemers despite legal action being taken against them by the state. I will discuss in detail one example, that of Yousaf Ali, who had been sentenced to death for blasphemy, and Tariq, who was on death row for murder. They were both in jail in Lahore when, in 2002, Tariq killed Yousaf, for which he was later acquitted in court; Chaudhry was his defence lawyer. Tariq has since been revered as a hero, a ghazi, with movies and literature created around his character. This case also highlights how the performance of violent action is experienced and construed as well as how it is narrated and glorified.

One December afternoon, while sitting with the KNLF lawyers at their bench in the Lahore Sessions Court, Chaudhry and his close companion Tahir Sultan started telling me about Tariq. They have a close relationship with Tariq and think of him as a saintly figure. According to them, Tariq was chosen by Allah to perform the very special task of killing the blasphemer and false claimant of prophethood, Yousaf, who is popularly called 'Yousaf Kazzab', meaning 'Yousaf the Liar'. Yousaf allegedly claimed to be a prophet and was sentenced to death in 2000 by a lower court. Chaudhry appeared as the prosecuting lawyer against Yousaf and also defended his murderer, Tariq, in court. The following account of Yousaf and Tariq highlights how Chaudhry and other members of the KNLF support the nonstate killing of blasphemers regardless of whether legal action has been taken against them by the state.

According to Chaudhry and his team, Yousaf was a leader of a selfproclaimed religious group and used to preach false beliefs in the name of Islam. He would lure people into coming to his special room with a promise of ziarat ('seeing') the Prophet; and, after going through some ritual procedures, he proclaimed himself the Prophet. He allegedly played this trick with several people, who testified against him in court. He also proclaimed in his sermons that certain verses of the Quran were narrated in reference to him. Thus, he was accused of preaching false beliefs and of indirectly committing blasphemy by posing as a prophet. The court sentenced him to death for insulting the Prophet and posing as a prophet, among other charges. 
Tariq was in the same prison as Yousaf on charges of murder. Another prisoner, who was Tariq's friend, had planned to kill Yousaf, but his plans were discovered and he was shifted to another jail. Before leaving, he told Tariq that it was now his duty to carry out the sacred task of killing Yousaf. Chaudhry and his team narrated the incident of that murder to me:

Tariq had smuggled the gun into the jail through a friend. He had a conversation with the gun while sitting in his prison cell and told it that he planned to kill a gustaakh-e-rasool ['blasphemer']. He begged the gun: 'Please be on my side and support me in this sacred endeavour.' After that, events turned out such that Allah Himself provided the perfect opportunity for the act of killing to take place. Yousaf walked past Tariq's cell as he was being shifted to another cell. Right at that time, Tariq was outside his cell for the regular walk that was allowed for 30 minutes every morning and 30 minutes every evening to all the prisoners. When he saw Yousaf coming, he ran back into his cell and brought the gun. He emptied all six bullets into Yousaf's body. Yousaf was a black magician so he tried to ward off the attack by reciting some verses and moving his hand in a particular way [a gesture of magic]. However, Allah made even his magic ineffective/void. At the same time, a whirl of wind blew in such a direction that the garbage from the ground started rising up and sticking to Yousaf's body under the pressure of the wind. Yousaf fell on the ground and died. Tariq handed the gun over to the police superintendent, rushed back to his cell and offered prayers of gratitude.

The lawyers emphasised repeatedly that the sequence of events was made possible and facilitated by Allah Himself. They believe Allah then favoured Tariq so that he was acquitted by the court despite having three charges of murder against him. They insisted that Tariq was not a very pious or practising Muslim; rather, he was chosen by Allah to perform this highly spiritual act. I asked Chaudhry whether I could meet Tariq and other ghazis he had been talking about. A friend of his, a journalist and self-proclaimed aashiq-e-rasool ('lover of the Prophet') who was sitting next to him, asked whether I would like to meet Ghazi Qadri, too. I was surprised as Qadri had been executed months before this conversation took place. Seeing confusion on my face, he said: 'Forget it, you won't understand, these are ideas of maarifat. They all exchanged glances and secretive smiles. I asked them to explain and, on my insistence, they agreed. Chaudhry asked whether I had listened to the qawwali ('devotional song') 'Oh disdaa meray peer wala werha' (lit.: 'There I See My Master's Courtyard'). I had not, so he went on to explain: 
The qawwali begins with the story of a man who had been sentenced to death by a king. However, whenever he was taken to the gallows, the rope broke mysteriously, safely landing him on to the ground. After several of these episodes, the king asked him to explain the matter. He smiled and said: 'Yeh meray pir ki karaamat hai [This is the miracle of my spiritual master].' When the king demanded to see his spiritual master, he replied that the only way to see his pir ['spiritual master'] was to change positions with him. He said: 'Come in my place [on the gallows] and then you will be able to see my pir.'

Chaudhry and his journalist friend explained to me that Qadri is a pir to them and, to be able to see him, one must be at an advanced stage of love called maarifat. They told me that maarifat is not for everyone; only chosen people experience this intense form of love and devotion.

Maarifat, karamat, pir and the notion of being chosen are specific concepts within the mystical tradition of Sufism in South Asian Islam (see, for example, Schimmel 1975; Werbner and Basu 1998). Here I will only briefly describe the meanings associated with these ideas in the Sufi mystic tradition. Sufis are mystics on a path or journey to the absolute truth that is, God (Schimmel 1975: 130-35). Ishq ('intense love') and maarifat ('inner knowledge or gnosis') are described as the last stations on this mystical path (Schimmel 1975). First, ish $q$ has been praised as the highest possible state of a mystic (Schimmel 1975) because hearts that love God will receive a vision of him. However, such a station of love cannot be achieved without the will of Allah-that is, by being chosen by him. Schimmel (1975: 138) describes this:

The mystics felt that the love they experienced was not their own work but was called into existence by God's activity ... God's love precedes human love. Only when God loves His servant can he love Him, and on the other hand, he cannot refuse to love God, since the initiative comes from God.

Second, gnosis or maarifat is the light of certainty gained through intuitive knowledge that is the only possible way of approaching the mystery of love. This is the kind of knowledge that is opposed to knowledge gained by reason. Sufi mystics have often shown disdain for intellect or knowledge gained by worldly discursive reason, as described by Schimmel (1975: 140): 'On the way of love, intellect is like the donkey that carries books; it is a lame ass'. 
The pir can thus be any spiritual leader who has been chosen by God to be in love with him. However, love of God is not possible without love of the Prophet Muhammad. Love of the Prophet is indeed seen as an essential stage leading to love of God. It was often termed fanaa-fi-rasul ('annihilation in the Prophet'). Hence, the Prophet is the ultimate spiritual leader or pir as all pirs enshrine his love (Schimmel 1975: 211-16). The Prophet Muhammad is the centre of devotion for mystics in Islam, as demonstrated by various forms of veneration including poetry, literature and performance. In fact, as Asani et al. (1995: 1) wrote in their book Celebrating Muhammad, no-one can estimate the power of Islam as a religion without first considering that at the heart of the tradition is love for the Prophet Muhammad.

Understanding the significance of these Sufi concepts and how they are employed in the discourse about nonstate violence against alleged blasphemers highlights the shift between reason-based and devotion-based discourses. Ghazis such as Tariq and Qadri are the chosen ones; they have been picked to love Allah and his Prophet by being given the opportunity (and spiritual powers) to punish alleged blasphemers. Their sense of right and wrong is thus derived not from discursive reason or state law. State law is merely an instrument to serve the ultimate truth-a truth that can only be gained by love and devotion. Their source of certainty and knowledge is the maarifat, the intuitive inner knowledge of the heart. They are also considered pirs because they have love of the ultimate pir-that is, the Prophet Muhammad-in their hearts. The KNLF lawyers themselves claim to be lovers of the Prophet and of those who are at a higher stage of loving the Prophet, the ghazis.

Another important concept that shapes their personal journeys on the 'path of love' is that of being sinners who pin their hopes of salvation to the love of the Prophet in their hearts. Throughout my research, I came across Pakistani Muslims who consider themselves sinful and in need of redemption and purification. In the story of Tariq, too, the lawyers told me he was not a pious practising Muslim. Rather, he was a sinner. But they rely on the mystical conception of the Prophet Muhammad as the intercessor for doomsday, who will intercede even for the greatest sinners of the Muslim community (Schimmel 1975: 10-11). The lawyers also have a sense of maarifat as they feel their understanding of the matters of the heart, or their inner knowledge, will be incomprehensible to outsiders who base their understanding on discursive reason. That is why they did not talk to me of these ideas until much later. The initial responses 
they gave were more inclined towards reason-based understandings of law, justice and exceptional circumstances. This implies that they are themselves conscious of the conflicts and contradictions between the matters of the heart and the matters of the mind with which they must deal every day. However, their reason-based responses also demonstrate an attempt to reconcile the two paradigms. It shows how they want the legal framework of the state to recognise matters of the heart. Intuitive knowledge or maarifat is the principle of decision-making for them, in terms of who is right and who is wrong, who should be punished and how, and they want this deeper sense of moral justice to prevail over the law of the state. By advocating against punishing those who carry out punishments of alleged blasphemers outside the law, they claim that the intuitive convictions of the heart should be acknowledged within the legal framework of the state.

\section{The lawyers' arguments inside the court}

So far, I have discussed two major narratives that the lawyers of KNLF employ to justify their support of nonstate violence against alleged blasphemers. First, they rely on reason-based arguments in which they blame the ineffectiveness of the legal system and exceptional circumstances for the occurrence of nonstate violence. Second, at a deeper level, they engage with narratives of devotion and passionate love as higher sources of morality. I also followed them into the courtroom, where they used a third set of arguments based on textual interpretations of Islamic law. They used some references to the Quran and hadith outside the courts as well, but they engaged with these sources in much greater detail inside the courtroom, where they used at least three sets of arguments: reason-based, passion-based and textual interpretations of religious sources. In terms of reason-based arguments, they relied on the concept of 'sudden and grave provocation'-a Western legal concept - to argue that those who kill blasphemers outside the law should not be held culpable as they act in self-defence against the attacks by blasphemers. They further argued that those who punish blasphemers outside the legal system are driven by their devotion and passionate love for the Prophet and hence should be absolved of any charges. Finally, they used references to the Quran and hadith to make their point and support their arguments through textual interpretations of Islamic law. 
Their references to Quranic verses and prophetic traditions demonstrated that Allah and the Prophet Muhammad had not only allowed, but also encouraged, the individuals who killed those who insulted the Prophet. ${ }^{2}$ Nonetheless, it is important to note that the lawyers' engagement with religious sources incorporated both reason and passion. Through discursive reasoning, they proved that the nonstate punishment of blasphemers is both rational and emotive, and that both aspects are valid provisions as per state law as well as Islamic law. I have argued throughout this book against the dichotomy of reason and passion in understanding the issue of blasphemy in Pakistan. The discourse of the KNLF lawyers further demonstrates that reason and passion are not only simultaneously present, but also mutually constitutive elements in the popular consciousness concerning the punishment of blasphemy. In the KNLF lawyers' worldview, it is completely reasonable for passionate lovers of the Prophet to kill alleged blasphemers outside the law based on their devotion and the provisions of Islamic law.

\section{The lawyers' shifting narratives: Strategic argumentation}

The discussion so far has shown multiple narratives on which the lawyers rely to justify their simultaneous support of state and nonstate punishments of blasphemy. Before moving on, I would like to emphasise that none of these narratives should be seen as either more or less valid than the other. The purpose of discussing these narratives is to highlight the multiple ways in which the lawyers as agents make meaning out of their work and strategically use those meanings to achieve certain ends. In interactions with outsiders (such as researchers like me, journalists and the media), they want to achieve acceptance as both professional lawyers and good Muslims who love the Prophet. They are uncertain as to whether or not these people share their devotional worldview, so they hesitate to bring up the narratives of passionate love and intuition. Hence, they are more likely to use reason-based arguments on the ineffectiveness of existing laws, which fosters a sense of injustice and helplessness. The narrative of victimhood of Muslims who are facing 'vile attacks against Islam and their beloved Prophet' is also more likely to be used in these

2 Most of these references were the same as quoted in Chapter 2 when describing the dominant religious discourse concerning blasphemy in Pakistan. 
circumstances as it portrays a clearer us versus them picture, establishes the existence of a threat to society and justifies blasphemy-related violence as a mechanism of self-defence.

In interactions with other forum members who are also seen as the 'circle of lovers of the Prophet', and within the wider community of lawyers, their aim is to project their piety and spirituality as being higher than that of other lawyers, to gain political and social influence (for example, in the legal associations) and legitimise their cause. Hence, they fall back on Sufi-mystic concepts of love, devotion and passion when talking to each other. Talking of these ideas also brings them respect within the larger community of lawyers for whom these ideas resonate with their own religious beliefs. In the courts, the aim is to win the argument by bringing in sources that cannot be denied. Therefore, they use references to sources of Islamic law in addition to their reason-based and passionbased arguments. Using religious texts and sources also asserts a certain pressure on the judges, which is very much an intended effect. Therefore, in addition to Western legal concepts, they rely on religious texts and scholarly works to strengthen not only their arguments but also their position vis-a-vis the opposing parties by siding with Allah and his Prophet. It must also be noted that the shift between narratives also coincides with a shift in the use of language. When discussing reasonbased justifications-such as self-defence, sudden provocation and other modern Western legal concepts-the lawyers use English words and terms. However, when talking about passion-based explanations and mystic ideas of love, devotion and intuitive knowledge, they usually use Urdu (the national language) or, even more so, Punjabi (the local language in Lahore). Thus, they not only shift between different arguments and narratives but also between different ontologies when speaking of different explanations for nonstate killings of blasphemers.

Nevertheless, these narratives should not be seen as mere means to certain ends; rather, they are meaningful and significant in their own right. They are both the motive and the means at the same time. They are actual belief systems and worldviews as well as carefully chosen arguments within specific circumstances. In fact, one of the main points I would like to assert is the continuity of what seems dissonant and discontinuous on the surface. The lawyers' discourse indeed presents a continuity and a coherent worldview constructed through various narratives and arguments. They are conscious of some of the contradictions and actively try to reconcile 
their worldview with the legal system. However, the different narratives they use-exceptional circumstances, devotion and religious law-are all components of a coherent ideology and way of life for them.

\section{The discourse of judges: The law and popular justice}

The judges deciding on cases of blasphemy also draw on multiple sources in their official judgements. They refer to modern legal principles and the sovereignty of the state as per the Constitution, religious sources and wider popular narratives. Their references to the sovereignty of the state and the Constitution distinguish between state and nonstate punishments. However, in the same judgements, they may refer to religious sources and other popular narratives that not only allow but also glorify nonstate punishment of alleged blasphemers. The judges' discourse also demonstrates that they find some discrepancies between 'the law of the land' and the legal ideal based on religious sources and popular justice. Let us first consider how the judges try to establish the state's monopoly over violence through references to the law. I will then discuss how they use religious sources and popular narratives in their judgements, through which they transcend the state's legality.

\section{The law and the state's monopoly over violent punishment}

In the recent Supreme Court judgement in Asia Bibi vs The State (2018: 13-14), the judges referred to Pakistan's Constitution:

It is worth mentioning that it is a matter of great pride and satisfaction that we are governed by a written Constitution and Statutory Laws. The Constitution, as per Article 4 thereof mandates that 'to enjoy the protection of law and to be treated in accordance with the law is an inalienable right of every citizen, wherever he may be, and of every other person for the time being within Pakistan. In particular (a) no action detrimental to the life, liberty, body, reputation or property of any person shall be taken except in accordance with law (b) no person shall be prevented from or be hindered in doing that which is not prohibited by law; and no person shall be compelled to do that which the law does not require him to do.' ... Thus, under the authority and 
command of the Constitution and the Law, it is the duty of the State to ensure that no incident of blasphemy shall take place in the country. In case of the commission of such [a] crime, only the State has the authority to bring the machinery of law into operation, bringing the accused before a Court of competent jurisdiction for trial in accordance with [the] law. However, it is not for the individuals, or a gathering [the mob], to decide as to whether any act falling within the purview of Section 295-C has been committed or not, because as stated earlier, it is the mandate of the Court to make such decision[s] after conducting a fully qualified trial and on the basis of credible evidence brought before it. No such parallel authority could in any circumstances be bestowed upon any individual or a group of persons.

In the above excerpt, the judges assert the state's authority by arguing that it is the only legitimate deliverer of punishment and nonstate actors cannot punish alleged blasphemers themselves. Similarly, in the case of Mumtaz Qadri vs The State (2015: 37-38), the Supreme Court judges argued the following while rejecting his appeal against his sentence for killing Salman Taseer:

The law of the land does not permit an individual to arrogate unto himself the roles of a complainant, prosecutor, judge and executioner. The appellant was a trained police officer who knew the importance of recourse to the law ... If the appellant had suspected Mr. Salman Taseer to have committed the offence of blasphemy, then he should also have adopted the legal course.

In these examples, we see the judges representing the state and trying to establish the authority and legitimacy of the state (and of their own judgements) based on the law. The law is thus called on as a source of legitimacy, but at the same time, the judges use it to excuse themselves for making decisions that may not be in line with popular ideas of justice. For example, in the same judgement in the case of Mumtaz Qadri vs The State (2015: 3), the judges provide the following disclaimer:

Without prejudice to the strong religious and philosophical views expressed before us we must state at the outset that we, in terms of our calling and vocation and in accord with the oath of our office, are obligated to decide this case in accordance with the law of the land as it exists and not in accordance with what the law should be. 
Hence, the law is presented as both a source of legitimacy and a limitation imposed on the judges by the state. The apparent rift between the law of the land' and 'what the law should be', as mentioned by the judges in the above excerpt, is also a space in which the judges exercise their own discretion in interpreting the law through discursive reasoning. I will now discuss how judges employ the religious discourse and popular narratives in their attempts to reconcile the rift between the law and popular justice, as well as in providing alternative sources of higher legality.

\section{Religious discourse and popular justice}

While the KNLF lawyers used religious sources to establish that alleged blasphemers must be punished violently (inside or outside the law), judges sometimes use religious sources to counter these arguments and acquit those accused of blasphemy. Lower court judges usually use the religious sources in the same way as do the KNLF lawyers. The highercourt judges, however, may take liberties more frequently to offer their own interpretations or use alternative religious sources. Nevertheless, the judges' authority to interpret Islamic law is not fully established or universally accepted. Their authority is challenged when they go against the established interpretations of religious sources concerning the punishment of blasphemy, based on various factors-including their Westernised outlook, the fact they are not 'religious scholars' and the suspicion that they are colluding with Western powers to undermine Islam. Consequently, judges have to appeal to popular sentiment by testifying their own faith and drawing on narratives of popular justice, especially when deciding in favour of those accused of blasphemy. In so doing, they not only coopt popular narratives and ideals of religiosity, but also give them legal approval. The following discussion will elaborate how judges employ religious sources and popular narratives in constructing their arguments and the impact on the overall understanding of justice and punishment for blasphemy in Pakistan.

Those accused of blasphemy are rarely acquitted by the trial courts due to external pressure from mobs and religious organisations on the decisions of the sessions courts. As a result, most cases of blasphemy are decided in favour of the accusers. The sessions court judges rely on religious sources to convict the accused, sometimes despite a lack of convincing evidence to 
prove the offence. For example, in the case of The State vs Liaqat Ali and Umar Draz, ${ }^{3}$ in which the accused allegedly denied the existence of Allah, the sessions court judge remarked:

There is no provision in the penal law of the country to take into task the person who used derogatory remarks in respect of the creator of this universe (The Almighty Allah), who is also creator of Hazrat Muhammad (PBUH). The lawmakers should give attention to this elapse [sic]. In this case, both the accused have made remarks more loudly regarding the Almighty Allah rather than the Holy Prophet Muhammad (PBUH). It chills the marrow of my bones that there is no law to set right such like people.

After having noted the discrepancy in the existing legal injunctions and his own sense of moral legality, he goes on, for three pages, quoting verses from the Quran and hadith to establish that insulting Allah is indeed an insult to the Prophet Muhammad as well. He writes conclusively:

In the light of above Quranic injunctions as well as from Ayati Mubarka and the prevailing law of the country on the subject, in the peculiar circumstances of this case, I feel no hesitation, keeping in view the conduct of the accused, that they deserve no leniency. (The State vs Liaqat Ali and Umar Draz 2009: 11)

Similarly, in The State vs Shafqat Masih and Mst. Shagufta Kousar (2014), ${ }^{4}$ the presiding sessions court judge quotes Quranic verses and narrations from prophetic tradition for more than five pages to establish the offence of the accused and sentence both to death for insulting the Prophet Muhammad and the Quran. Furthermore, there are a number of cases in which the judges have relied on Quranic and hadith material to convict the accused, even in the absence of convincing legal evidence against them. In such instances, the judges have often relied on an earlier statement by a High Court judge that witnesses are not required to repeat offensive or derogatory words allegedly uttered by the accused to establish their claims under Section 295-C of the PPC. Many judges have referred to this judgement to justify bypassing the necessity of producing evidence in court and to convict the accused on the basis of religious arguments alone:

3 The State vs Liaqat Ali and Umar Draz (2009) FIR No. 166 dated 21 March 2006, Sessions Court Jhang: 8 .

4 The State vs Shafqat Masih and Mst. Shagufta Kousar (2014) Sessions Trial No. 5-14 of 2014, Sessions Court Toba Tek Singh. 
To constitute [an] offence under section 295-C, PPC [Pakistan Penal Code,] [a] number witnesses are not required and it is not necessary that such abusive language should be made loudly in public or in a meeting or at some specific place, but [the] statement of [a] single witness that somebody had made [an] utterance for the contempt of the Holy Prophet (Peace be upon Him) even inside the house is sufficient to award [the] death penalty to such [a] contemnor. ${ }^{5}$

Thus, in the absence of the requirement for evidence, religious sources are used as both the logic and the content of the evidence to convict and punish people accused of blasphemy. On the other hand, judges (often in the higher courts) also use legal discourse to contest the dominant interpretations and offer alternative religious sources. For example, in a 2002 judgement, which was widely quoted in later judgements related to blasphemy, the Lahore High Court judge gave his own interpretation of blasphemy as follows:

The greatest blasphemy of all is a child going hungry, a child condemned to the slow death of starvation. The miscarriage of justice is blasphemy. Misgovernment is blasphemy. An unconscionable gap between rich and poor is blasphemy. Denial of treatment to the sick, denial of education to the child, are alike examples of blasphemy. ${ }^{6}$

In a more recent judgement (in February 2017), the Lahore High Court asserted the need for followers of the Prophet Muhammad to adopt an attitude of forgiveness and mercy:

Increase in the number of registration [sic] of blasphemy cases and [the] element of mischief involved therein calls for extra care at the end of the prosecution. Registration of such like cases cannot be allowed in a free and careless manner and ordinary citizens who have not much knowledge of religion must not be allowed to use the law in question to settle their scores. All this we are doing in the name of our Holy Prophet Hazrat Muhammad (Peace Be Upon Him), who is 'Rehmatu-lil-Aalmeen' ['mercy for all the worlds'] and being 'Bashir' ['one who brings good news'] has given assurance that even if [the] whole of ... [one's life is] spent in sins,

5 Haji Bashir Ahmad vs The State (2005) YLR 985, Lahore High Court.

6 Muhammad Mahboob alias Booba vs The State (2002) PLD Lahore 587. Available from: cite.pak caselaw.com/pld-lahore-high-court-lahore/2002/587/. 
but before a person breathes his last, [he] has recited 'Kalma Pak' ['declaration of faith'], [he] is entitled to be relieved from all his sins by Allah Almighty on the day of judgment. ${ }^{7}$

Hence, references to religious sources are used not only to convict the accused but also to make opposing arguments. The alternative interpretations may also become precedents that are called on in future judgements. However, appealing to religious sources even in the most progressive of judgements may also set precedents that justify nonstate punishment of blasphemers. I have already mentioned the Supreme Court judgement in the case of Mumtaz Qadri vs The State (2015) in which the judges argued that Qadri was not justified in taking 'the law' into his own hands. This is seen as one of the most 'progressive' judgements to come out of the courts of Pakistan on the matter of the nonstate killing of blasphemers as it upheld the death penalty for Mumtaz Qadri. However, even in this judgement, the judges allowed for the possibility of a legitimate killing of a blasphemer by nonstate actors. I will quote from the judgement at some length to illustrate this point:

We as Muslims are fully aware and convinced of the most exalted position held by the Holy Prophet Muhammad (peace be upon Him) in the eyes of Almighty Allah as well as in the hearts and minds of the Ummah and the followers of the Islamic faith. It goes without saying that deepest respect and profound reverence for the Holy Prophet Muhammad (peace be upon Him) is an article of faith with all of us. Be that as it may the issue involved in this case is not as to whether anybody is allowed to commit blasphemy by defiling the sacred name of the Holy Prophet Muhammad (peace be upon him) or not or as to whether a person committing blasphemy can be killed by another person on his own or not but the real question involved in the present case is as to whether or not a person can be said to be justified in killing another person on his own on the basis of an unverified impression or an unestablished perception that such other person has committed blasphemy. (Mumtaz Qadri vs The State 2015: 22; emphasis added)

There are two important points to note in the above excerpt. First, the judges had to make a declaration of their own faith and attest to the sanctity of Allah and his Prophet before making their judgement. Second, the judges did not condemn the nonstate killing of a blasphemer

7 Muhammad Ishaq vs The State (2017) HCJDA 38, Lahore High Court: 19. 
in principle; they only denounced the fact that the said killing was carried out on the basis of unverified and unestablished evidence. Further on in the same judgement, the judges appear to accept the religious sources presented to them by the lawyers with regard to the legality and legitimacy of killing a blasphemer outside the law. The following passage from the judgement demonstrates the judges' position on the religious sources:

A close and careful examination of all the references made and the religious material produced in this case by the appellant and his learned counsel shows, and shows quite clearly and unmistakably, that such references and material pertain to cases where commission of blasphemy stands established as a fact and then the discussion is about how the apostate may be treated and not a single reference made or instance referred to in the material produced permits killing of a person on the basis only of an unverified impression or an unestablished perception regarding commission of blasphemy. (Mumtaz Qadri vs The State 2015: 22)

Hence, it is clear that the blasphemer or apostate (both words are used interchangeably by the judges) may be killed by nonstate actors if the offence is established. While the judges may have exercised strategic discretion in this case to avoid controversy by dismissing the religious sources submitted to them, they did set a precedent that may be referred to in future judgements on the matter. Moreover, in making their argument that Mumtaz Qadri was not justified in the killing because he did not have sufficient evidence to establish that the offence was committed, they did not simply use the modern legal concepts concerning offence and evidence. They referred to the Quran to assert the correctness of their argument:

As mentioned above, in the Holy Qur'an Almighty Allah has repeatedly warned those who start believing in hearsay without getting it ascertained, verified or investigated or conduct themselves on the basis of such hearsay. The appellant, therefore, would have done better if, notwithstanding his professed religious motivation in the matter, he had paid heed to those warnings of Almighty Allah as well before an unjustified killing of another on the sole basis of hearsay. An unjustified killing of a human being has been declared by Almighty Allah as murder of the entire mankind. (Mumtaz Qadri vs The State 2015: 22-23) 
Here we see the judges offering their own interpretation of a religious source to make their argument-in this case, against an individual who killed an alleged blasphemer. As seen in other, earlier cases, judges engage with the religious sources in multiple ways, accepting some and offering their own interpretations of others. Regardless, it is through this discursive reasoning drawing on the law as well as religious sources that they construct their arguments both in favour of and against the punishment of alleged blasphemers. In so doing, they also set precedents - that may be positive or negative-for future cases. For example, the following passage written by the Supreme Court judges in the Mumtaz Qadri vs The State (2015) judgement was recently used by the judges in the case of Asia Bibi vs The State (2018: 28):

Commission of blasphemy is abhorrent and immoral besides being a manifestation of intolerance but at the same time a false allegation regarding commission of such an offence is equally detestable besides being culpable. If our religion of Islam comes down heavily upon commission of blasphemy, then Islam is also very tough against those who level false allegations of a crime. It is, therefore, for the State of the Islamic Republic of Pakistan to ensure that no innocent person is compelled or constrained to face an investigation or a trial on the basis of false or trumped up allegations regarding commission of such an offence.

The above passage was used by the Supreme Court judges in 2018 to acquit Asia Bibi. Thus, in this case, we see the judges' intervention led to a positive precedent that may be drawn on in future. However, as noted in earlier cases, the judges in the case of Asia Bibi also made appeals to popular sentiment to establish the legitimacy of their judgement. They started the judgement with the following proclamation:

'I bear witness that there is no God worthy to be worshiped but Allah, and I bear witness that Muhammad is the Last Messenger of Allah.' The Qalimah-e-Shahadat ['profession of faith'] as shown above, is deemed to be the essence of Islam and the recitation of which makes us Muslims, is self-explanatory and testifies that there is no God but Allah and our Prophet Muhammad [Jلص ملص [ [لسو ميلع is the Last Messenger of Allah. It is our declaration of faith in the unseen and belief, to bow down our heads before our Lord Allah, admitting the fact that there is none like Him. The

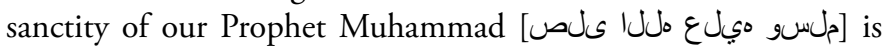
further evident from the Qalimah-e-Shahadat, as His name is being 
read together with Allah, thus ultimate care and great importance should be drawn while taking this Holy name. (Asia Bibi vs The State 2018: 1)

Once again, giving the affirmation of faith before deciding in favour of a person accused of blasphemy may very well be a strategic move by the judges to establish their authority and claim legitimacy on the basis of their faith. However, they did not stop there. They went on to refer not only to the religious sources (Quran and hadith) but also to popular narratives that legitimise and glorify the killing of blasphemers outside the law. In Chapter 2, I mentioned a couplet by Muhammad Iqbal-a poet celebrated as the ideological father of Pakistan-used by almost all religious groups campaigning for strict punishment for blasphemers. The couplet talks about love of the Prophet Muhammad as a guaranteed way to command Allah's 'pen of destiny'. The Supreme Court judges also referred to the same couplet in their judgement in the case of Asia Bibi. They wrote:

As it is enunciated in the above verse of Allama Muhammad Iqbal, a well renowned activist and the 'Spiritual Father of Pakistan', from his poem Jawab-e-Shikwa, the veneration and adulation of

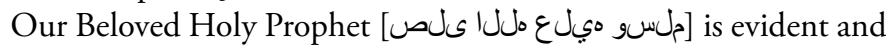
is reckoned as the foundational principle on which the religion Islam is based. There is no denial whatsoever of the fact that Prophet Muhammad [ملسو ميلع ملا علص] holds the utmost respect, prestige and dignity amongst the Muslim Ummah and possesses the highest rank and status compared to all Creatures shaped by Allah Almighty, even the Messengers of Allah who came before him. (Asia Bibi vs The State 2018: 3)

They further referred to the popular narratives concerning Ghazi Ilmuddin, giving credence to the idea of nonstate killings of alleged blasphemers. They write:

Reference may be made to an incident which occurred in 1923 , when one said person, Rajpal, published a pamphlet/book containing derogatory remarks against Prophet Muhammad [ملسو ميلع مل ال علص]. A movement was launched by the Muslims of the sub-continent demanding a ban on the book. As a result, in 1927 the British Government was forced to enact a law prohibiting insults aimed at founders and leaders of religious communities, as such, section 295-A was inserted in the Pakistan Penal Code in the year 1927. However, the Muslims were not 
satisfied with it and one Ghazi Ilm-ud-Din Shaheed succeeded in murdering Rajpal. After the trial, Ilm-ud-Din was convicted and was given [the] death penalty. He is considered by the Muslims to be a great lover of the Prophet. (Asia Bibi vs The State 2018: 9)

The judges called Ilmuddin a martyr, despite noting that he went against the law at the time to kill an alleged blasphemer. They further affirmed that he is accepted by Muslims as a hero and a great lover of the Prophet. It must be noted that the state in power at the time, Britain, is considered less legitimate than the current state of Pakistan in the eyes of the people. So, the judges could have been implying that Ilmuddin's act was justified in the context of British rule but would not be in the present context of Pakistan, an Islamic state. Nevertheless, as already discussed, the proponents of nonstate killings of blasphemers do not fully accept the legitimacy of the current state of Pakistan either. Within this context, a reference to Ilmuddin as an accepted lover of the Prophet sends a message to those who use Ilmuddin's story to carry out similar acts of nonstate punishment in the present day that their acts are justified.

Hence, to establish their legitimacy and credibility, the judges refer not only to the religious sources (Quran and hadith), but also to popular narratives concerning nonstate punishment of alleged blasphemers. There are clearly external pressures-including threats to their lives-under which the judges operate and decide on cases of blasphemy. Therefore, their appeal to religious sources and popular narratives may simply be a tactic to ensure their own safety. The judges may also be doing so to establish themselves as good Muslims and lovers of the Prophet to avert criticism of their judgements as anti-religious. In some instances, the judges may also truly believe in the narratives they are employing and appealing to in their judgements. Nevertheless, the fact that judges have to draw on ideas of popular justice highlights the symbolic power of these narratives. It also reiterates the fact that the legal system is not the only source of legality and legitimacy. In fact, the law is constantly held accountable to higher sources of morality and justice, and judges must appeal to those sources-religious texts and popular narratives-even when they are deciding in accordance with state law. References to the law are therefore not sufficient in establishing the legitimacy of their decisions. The state, despite its claim to represent Islamic law, does not hold a monopoly over the interpretation and implementation of what is thought to be Islamic law. The 'law of the land' is hence subservient to 'what the law should 
be' and, through their discursive reasoning within their judgements, the judges constantly attempt to reconcile the two. Despite the apparent incongruities, the discourse of judges also demonstrates a continuity between the law, religious sources and popular narratives.

\section{Conclusion}

In discussing the discourses of the lawyers and the judges, I have focused mainly on the microlevel continuities between the different narratives and arguments they employ. However, the implications of my analysis must be understood at two different levels: individual and structural. At the individual level, I argue that reason and passion are both present and mutually constitutive in constructing the worldviews and strategic arguments of the lawyers and the judges. I have demonstrated that both groups draw on multiple sources of legitimacy to establish the legality of their judgements concerning the appropriate punishment of blasphemy. The law is therefore not a sufficient source of legitimacy despite the state's claim to represent Islamic law. There is in fact a constant dialogue between the ideals of Islamic law-as per various actors in society-and the existing laws of the state. The lawyers and the judges, being at the nexus of the state and society, deal with the dilemmas concerning the appropriate punishment of blasphemers on an everyday basis. Both groups construct meaningful and strategic arguments drawing on multiple sources of morality and legality within the specific contexts and circumstances of the cases with which they are dealing. I argue that the shifting narratives and multiple arguments of the judges and lawyers should not be seen as either solely motivated by their belief systems or entirely tactical in nature. Instead, their arguments provide them with meaning and strategic benefits at the same time. The meaning is not static; rather, it is constantly constructed within specific circumstances and is derived from the process of contestation itself. It is within this process of meaning creation that the strategic arguments are also constructed. Hence, the multiple sources of legitimacy and morality are both means and motives at the same time. Moreover, the multiple narratives used by the lawyers and the judges bring reason-based and passion-based arguments together in constructing a coherent worldview. 
At the structural level, I argue that state and nonstate ideals of the appropriate punishment for an alleged blasphemer are extensions of each other rather than opposing forces. The state of Pakistan not only claims to be an Islamic state but is also itself an embodiment of the popular narratives concerning religious symbols. I mentioned in Chapter 1 that the Ilmuddin controversy was one of the major events involving mobilisation around religious symbols in the leadup to the creation of Pakistan. I have also mentioned that Jinnah, the main architect of Pakistan, represented Ilmuddin in the British courts, and Muhammad Iqbal, the ideological father of Pakistan, led Ilmuddin's funeral prayers. The popular narratives glorifying the nonstate punishment of alleged blasphemers are therefore embedded within the foundation of Pakistan. Pakistan's anti-blasphemy laws have further strengthened this foundation within the existing structure of the state. The foundational and structural violence of the state in Pakistan is, then, not very different from the nonstate violence carried out against those accused of blasphemy. I argue that the state and nonstate punishments of alleged blasphemers, and their sources of legitimacy, are indeed extensions of each other. From a state-centric perspective, the nonstate punishment of blasphemers has often been described as anti-state and delinquent. On the other hand, the modern state has been demonised as the sole culprit of structural and foundational violence. I argue that any useful understanding of blasphemy-related violence in Pakistan must look at state and nonstate violence as mutually constitutive. 
This text is taken from Finding the Enemy Within: Blasphemy Accusations and Subsequent Violence in Pakistan, by Sana Ashraf, published 2021 by ANU Press, The Australian National University, Canberra, Australia.

doi.org/10.22459/FEW.2021.06 